\title{
Meningkatkan Keaktifan dan Hasil Belajar IPS Melalui Metode Time Token Siswa Kelas VIII D SMP Negeri 24 Kota Jambi
}

\author{
Tianna Simanjuntak \\ Guru SMP Negeri 24 Kota Jambi \\ email: tianasimanjuntak@yahoo.co.id
}

\begin{abstract}
This research was motivated because of the students of class VIII D of SMP 24 Jambi tend to be passive and challenging to be invited to be more active, creative, and confident. For example, students have not dared to ask if they do not understand. In addition to that, the studentswere silent and did not express their opinionsin a class discussion. Thus, the learning processof the classroom was less effective and conducive. One of the steps taken is to use the Time Token learning method. In this method, students are required to be more active in expressing their opinions and to be able to listen to the opinions of others. The purpose of this study is to find out how big the effect of the Time Token method can improve student activity and learning outcomes in social studies. This research is a class action research (PTK) with the class VIII D as the subject in the oddsemester. Data collection methodologies used in this study are experiment and observation methods. The collected data was analyzed by qualitative descriptive analysis. The results showed that there was an increase in activity and learning outcomes in social studies subjects after using the Time Token learning method during the implementation of the action.The average activity of the first cycle was $69.82 \%$ and it increased to $88.42 \%$ in the second cycle. Furthermore, the increase in student learning outcomes that have fulfilled the completeness value was of 7.89\% in the first cycle butin the second cycle there was an increase, which became to 92.11 .
\end{abstract}

Keywords: learning activities, learning outcomes, Time Token method

\begin{abstract}
Abstrak: Penelitian ini dilatarbelakangi karena siswa kelas VIII D SMP 24 Jambi cenderung pasif dan menantang untuk diajak lebih aktif, kreatif, dan percaya diri. Misalnya, siswa belum berani bertanya apakah mereka tidak mengerti. Selain itu, para siswa diam dan tidak mengungkapkan pendapat mereka dalam diskusi kelas. Dengan demikian, proses pembelajaran di kelas kurang efektif dan kondusif. Salah satu langkah yang diambil adalah menggunakan metode pembelajaran Time Token. Dalam metode ini, siswa dituntut untuk lebih aktif dalam mengekspresikan pendapatnya dan untuk dapat mendengarkan pendapat orang lain. Tujuan dari penelitian ini adalah untuk mengetahui seberapa besar pengaruh metode Time Token dapat meningkatkan aktivitas siswa dan hasil belajar dalam studi sosial. Penelitian ini adalah penelitian tindakan kelas (PTK) dengan kelas VIII D sebagai subjek dalam oddsemester. Metodologi pengumpulan data yang digunakan dalam penelitian ini adalah metode eksperimen dan observasi. Data yang terkumpul dianalisis dengan analisis deskriptif kualitatif. Hasil penelitian menunjukkan bahwa ada peningkatan aktivitas dan hasil belajar dalam mata pelajaran sosial setelah menggunakan metode pembelajaran Time Token selama pelaksanaan tindakan. Aktivitas rata-rata siklus pertama adalah $69,82 \%$ dan meningkat menjadi 88,42\% di kedua. siklus. Selanjutnya, peningkatan hasil belajar siswa yang telah memenuhi nilai ketuntasan adalah sebesar 7,89\% pada siklus pertama tetapi pada siklus kedua ada peningkatan, yaitu menjadi 92,11.
\end{abstract}

Kata kunci: kegiatan belajar, hasil belajar, metode Time Token

\section{PENDAHULUAN}

Pendidikan merupakan bidang yang sangat berpengaruh untuk meningkatkan kualitas Sumber Daya Manusia (SDM). Pendidikan berkembang seiring dengan perkembangan Ilmu Pengetahuan dan Teknologi (IPTEK). Segala sesuatu yang berhubungan dengan pendidikan harus dapat menyesuaikan perkembangan IPTEK. Hal ini terjadi karena pada abad terakhir ini manusia dikatakan unggul apabila mereka berpendidikan dan menguasai teknologi. Pendidikan yang semakin baik diharapkan akan menghasilkan SDM yang semakin baik pula. Oleh karena itu, perpaduan antara teknologi dan pendidikan berperan untuk membentuk SDM yang cakap, kreatif, terampil dan profesional.

Ilmu pengetahuan sosial (IPS) merupakan salah satu cabang ilmu yang dipelajari sejak kita mengenal dunia dan tidak akan pernah berakhir untuk dipelajari, karena IPS merupakan ilmu yang sangat dekat dengan keseharian kita sehingga baik secara formal maupun informal kita akan tetap mempelajarinya.

Menurut Susanto (2014:6) Ilmu Pengetahuan Sosial (IPS) merupakan integrasi dari berbagai cabang ilmu-ilmu sosial dan humaniora yaitu: Sosiologi, sejarah, geografi, ekonomi, politik, hukum, dan budaya. Ilmu pengetahuan sosial di rumuskan atas dasar realitas dan fenomena sosial yamg mewujudkan suatu pendekatan interdisipliner dari aspek dan cabang-cabang ilmu sosial ( sosiologi, sejarah, geografi, ekonomi, politik, hukum dan budaya). 
Peraturan Menteri Pendidikan Nasional No. 22 tahun 2006 tentang Standar Isi Satuan Pendidikan Dasar dan Menengah yang memuat Standar Kompetensi dan Kompetensi Dasar (SKKD) Ilmu Pengetahuan Sosial (IPS) di tingkat Sekolah Menengah Pertama (SMP), mencakup materi geografi, sejarah, ekonomi, dan sosiologi. Mata pelajaran IPS disusun secara sistematis, komprehensif dan terpadu, dengan pembelajaran terpadu diharapkan pembelajaran IPS menjadi lebih bermakna bagi peserta didik dalam konteks kehidupan sehari-hari. Siswa akan memperoleh pemahaman yang lebih utuh dan lebih luas.

Adapun menurut Chapin dan Messik dalam Susanto (2014: ) bahwa tujuan pembelajaran IPS dapat dikelompokan menjadi enam komponen, yaitu:

1. Memberikan pengetahuan tentang pengalaman manusia dalam bermasyarakat pada masa lalu, sekarang, dan akan datang.

2. Mengembangkan keterampilan untuk mencari dan mengolah informasi.

3. Mengembangkan nilai sikap demokrasi pada masyarakat.

4. Menyediakan kesempatan siswa untuk berperan serta dalam kehidupan sosial.

5. Ditunjukan pada pembekalan pengetahuan, pengembangan berfikir, dan kemampuan berfikir kritis, melatih membebaskan keterampilan dan kebiasaan.

6. Ditunjukan pada peserta didik untuk mampu memahami hal yang bersifat kongret, realistis dalam kehidupan sosial.

Tujuan utama ilmu pengetahuan sosial adalah untuk mengembangkan potensi peserta didik agar peka terhadap masalah sosial yang terjadi dimasyarakat, memiliki sikap mental positif, perbaikan segala ketimpangan yang terjadi, dan terampil mengatasi setiap masalah yang terjadi sehari-hari, baik yang menimpa dirinya sendiri maupun yang menimpa masyarakat.

Untuk menunjang kesuksesan penyelenggaraan pendidikan, perlu menyediakan lingkungan yang memungkinkan peserta didik dapat mengembangkan bakat dan kemampuan secara optimal. Peserta didik atau siswa dapat mewujudkan dirinya dan berfungsi sepenuhnya, sesuai dengan kebutuhan pribadinya dan kebutuhan masyarakat sesuai dengan tujuan pendidikan nasional yang tertera dalam Undang-undang RI Nomor 20 tahun 2003 tentang Sistem Pendidikan Nasional pasal 3, yaitu yang berbunyi untuk mengembangkan potensi peserta didik agar menjadi manusia yang berakhlak mulia, sehat, berilmu, cakap, kreatif, mandiri, dan menjadi warga negara yang demokratis serta bertanggung jawab dan berfungsi mengembangkan kemampuan dan membentuk watak serta peradaban bangsa yang bermanfaat dalam rangka mencerdaskan kehidupan bangsa.

Dalam penyampaian kompetensi IPS terpadu terdapat kendala atau hambatan yang dihadapi baik dari pihak guru atau peserta didik. Misalnya, guru belum menguasai kompetensi yang akan diajarkan, tidak terdapat dukungan media pembelajaran, peserta didik belum siap menerima pelajaran dan metode mengajar guru yang monoton. Berdasarkan hasil observasi pembelajaran IPS di Kelas VIIID di SMP Negeri 24 Kota Jambi juga terdapat kendala yang sama, yaitu materi- materi IPS diajarkan secara terpisah. kendala yang lain. yaitu pembelajaran yang dilaksanakan secara monoton melalui metode ceramah membuat peserta didik kurang antusias dalam menghadapi pembelajaran sehingga peserta didik jarang bertanya tentang pelajaran yang belum dipahami oleh siswa, sehingga siswa hanya mendengarkan guru menyampaikan materi pembelajaran. Hasil belajar siswa juga hanya pada tingkatan paling rendah, yaitu pada tingkatan mengingat saja karena siswa hanya menghafalkan apa yang dicatat dari guru dan yang ada di buku paket. Hal ini bertentangan dengan pernyataan berikut:

"Belajar bukanlah semata kegiatan menghafal, banyak hal yang diingat akan hilang dalam beberapa jam. Mempelajari bukanlah menelan semuanya. Siswa harus mengolah dan memahami materi pelajaran untuk mengingat apa yang telah diajarkan oleh guru mereka. Seorang guru juga tidak bisa serta merta menuangkan sesuatu ke dalam benak siswanya, karena mereka sendirilah yang harus menata apa yang mereka dengar, lihat, menjadi satu kesatuan yang bermakna. Proses belajar perlu dilakukan secara bergelombang, kedekatan dengan materi yang dipelajari, jauh sebelum mempelajarinya" (Melvin L. Silberman, 2009: 27).

Menurut Rusman (2012:123) mengemukakan bahwa hasil belajar adalah sejumlah pengalaman yang diperoleh siswa yang mencakup ranah kognitif, afektif, dan psikomotorik. Sedangkan menurut Winkel dalam Purwanto (2013: 45) mengemukakan bahwa hasil belajar adalah perubahan yang mengakibatkan manusia berubah dalam sikap dan tingkah lakunya. Menurut Asep dan Abdul (2012:14) Bahwa hasil belajar 
pencapaian bentuk perubahan perilaku yang cendrung menetap dari ranah kognitif, apektif, dan psikomotorik dari proses belajar dalam waktu tertentu.

Dapat disimpulkan bahwa hasil belajar merupakan tolak ukur yang dapat digunakan untuk melihat keberhasilan siswa dalam proses belajar mengajar yang dilihat dari tiga aspek yaitu aspek koqnitif, aspek apektif dan psikomotor, Yang pada akhirnya akan menghasilkan pengetahuan, sikap dan keterampilan yang akan membawa pada perubahan tingkah laku. Perubahan yang terjadi akan berlangsung dalam jangka waktu tertentu yang nantinya berguna dalam kehidupan dan proses belajar selanjutnya.

Dalam melakukan aktifitas belajar akan dipengaruhi oleh berbagai faktor yang akan berpengaruh pada hasil belajar siswa, baik faktor dari dalam (internal) maupun faktor dari luar (eksternal). Hasil belajar yang optimal tidak terlepas dari faktor-faktor yang mempengaruhi hasil belajar. Menurut Slameto (2013:54)faktor-faktor yang memengaruhi hasil belajar adalah: 1) Faktor Internal. Faktor internal yaitu faktor yang timbul dari dalam diri siswa itu sendiri. Di dalam faktor internal terdapat lagi tiga faktor yang terdiri dari: faktor jasmaniah, faktor psikologos, dan faktor kelelahan. 2) Faktor Eksternal. Faktor eksternal yaitu faktor yang timbul dari luar diri siswa itu sendiri. Di dalam faktor eksternal ini terdiri dari tiga faktor, yaitu faktor keluarga, faktor sekolah, dan faktor masyarakat.

Faktor yang mempengaruhi hasil belajar pada dasarnya adalah segala sesuatu pengaruh yang datang dari luar dan dalam diri siswa,faktor ekstern yang berasal dari luar diri siswa seperti didalamnya terdapat model belajar, media/ alat pembelajaran. Model pembelajaran yang digunakan dalam penelitian ini adalah Time Token.

Dalam metode pembelajaran Time Token, siswa dituntut untuk mampu lebih aktif mengungkapkan pendapatnya dalam pembelajaran dan dapat mendengarkan pendapat orang lain. Keunggulan dari metode Time Token adalah semua siswa aktif memberikan pendapat dalam kegiatan pembelajaran dan dapat menumbuhkan keberanian siswa dalam berpendapat bagi siswa yang pemalu dan sukar bicara. Pembelajaran Time Token menekankan pada aktivitas dan interaksi diantara siswa untuk saling membantu dalam menguasai materi pelajaran guna mencapai hasil yang maksimal.

Metode pembelajaran Time Token merupakan salah satu pendekatan struktural dalam pembelajaran kooperatif yang dirancang untuk mempengaruhi pola interaksi siswa dan meningkatkan perolehan hasil belajar. Tipe pembelajaran ini dimaksudkan sebagai alternatif untuk mengajarkan keterampilan sosial yang bertujuan untuk menghindari siswa mendominasi atau siswa diam sama sekali dan menghendaki siswa saling membantu dalam kelompok kecil dan lebih dicirikan oleh penghargaan kooperatif daripada individu (Slavin, 2010: 113).

Pembelajaran Time Token melibatkan lebih banyak siswa dalam menelaah materi yang tercakup dalam suatu pelajaran dan mengecek pemahaman mereka terhadap isi pelajaran tersebut. Metode pembelajaran ini sangat tepat digunakan untuk pembelajaran struktur yang dapat digunakan untuk mengajar keterampilan sosial untuk menghindari siswa mendominasi pembicaraan atau siswa diam.

Langkah-langkah pembelajaran dalam Agus Suprijono (2011: 133) metode pembelajaran Time Token, sebagai berikut:

1. Guru menjelaskan tujuan pembelajaran/KD.

2. Guru mengkondisikan kelas untuk melaksanakan diskusi (Cooperative Learning/CL).

3. Tiap siswa diberi sejumlah kupon berbicara dengan waktu lebih kurang 30 detik per kupon. Setiap siswa diberi sejumlah nilai sesuai waktu yang digunakan.

4. Bila telah selesai bicara, kupon yang dipegang siswa diserahkan kepada guru. Setiap tampil berbicara satu kupon. Siswa dapat tampil lagi setelah bergiliran dengan siswa lainnya.

5. Siswa yang telah habis kuponnya tidak boleh berbicara lagi. Siswa yang masih memegang kupon harus bicara sampai semua kuponnya habis.

6. Demikian seterusnya

Metode Time Token menekankan agar siswa mengungkapkan pendapat ataupun menjawab pertanyaan sesuai dengan kemampuannya, sehingga tidak ada dominasi pembicaraan dari siswa yang lebih pintar. Langkah-langkah metode Time Token adalah guru menjelaskan tujuan pembelajaran, guru mengkondisikan kelas untuk pelaksanaan diskusi, pemberian sejumlah 2 kupon berbicara oleh guru kepada setiap siswa untuk dapat berbicara dengan waktu 30 detik per kupon, setelah selesai berbicara kupon diberikan kepada guru, dan siswa yang sudah habis kuponnya tidak boleh berbicara lagi. Menggunakan metode Time Token untuk 
proses pembelajaran juga mempunyai kelebihan dan kelemahan. Kelebihannya yaitu semua siswa berbicara, melatih keberanian siswa, sedangkan kelemahannya yaitu guru harus menyiapkan pertanyaan yang banyak, dan siswa yang memiliki banyak pendapat akan sulit mengutarakan pendapatnya karena waktu yang terbatas.

Berdasarkan uraian di atas, peneliti tertarik melaksanakan penelitian dengan judul "Meningkatan Keaktifan dan Hasil Belajar IPS Melalui Metode Time Token Siswa Kelas VIIID di SMP Negeri 24 Kota Jambi”. Tujuan diadakannya penelitian ini adalah: 1) Untuk mengetahui seberapa besar metode Time Token dapat meningkatkan keaktifan dan hasil belajar siswa dalam pembelajaran IPS. 2) Untuk mendapatkan bukti-bukti bahwa metode pembelajaran Time Token dapat meningkatkan keaktifan dan hasil belajar siswa dalam pembelajaran IPS.

\section{METODE PENELITIAN}

Jenis penelitian yang dilaksanakan ini adalah Penelitian Tindakan Kelas (Classroom Action Research), yaitu penelitian tindakan yang dilakukan di kelas dengan tujuan memperbaiki mutu praktek pembelajaran di kelas. Penelitian tindakan kelas ini mengambil desain yang dikembangkan oleh Kemmis dan Mc Taggart yang merupakan pengembangan dari konsep Kurt Lewin. Skema Model Kemmis \& Mc Taggart (Suwarsih Madya, 2007: 67) dapat dilihat pada gambar berikut.

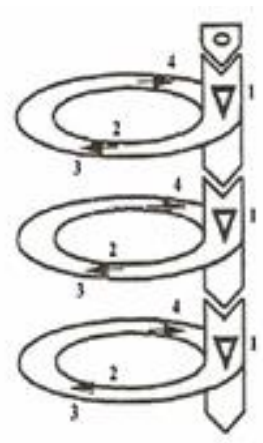

Keterangan:

1. Perencanaan (planning)

2. Pelaksanaan Tindakan (action)

3. Pengamatan (observation)

4. Refleksi (reflection)

\section{Gambar 1. Alur Penelitian Tindakan Kelas}

Subjek dalam Penelitian Tindakan Kelas ini adalah siswa kelas VIII D SMP Negeri 24 Kota Jambi Jambi dengan jumlah siswa 38 orang, terdiri dari 15 siswa laki-laki dan 23 siswa perempuan. Peneliti melaksanakan penelitian pada mata pelajaran Ilmu Pengetahuan Sosial (IPS) dengan materi perubahan sosial budaya.

Teknik pengumpulan data dilakukan melalui dua cara yaitu: Tes dan Observasi. Adapun instrumen yang digunakan untuk tes adalah berupa soal tes dan instrumen untuk observasi adalah berupa lembar observasi.

Teknik analisis data digunakan dalam penelitian ini adalah model analisis kualitatif dengan model interaktif (Milles dan Hubberman, 1992: 16-17).

\section{HASIL PENELITIAN \\ Siklus 1}

Siklus pertama dilaksanakan dalam dua kali pertemuan dengan alokasi waktu 4 jam pelajaran, yaitu pada tanggal 30 Oktober 2018 dan 1 November 2018. Pada siklus I pembelajaran dilakukan selama 2 x 35 menit, dengan materi perubahan sosial budaya. Dalam hal ini peneliti bertindak sebagai guru. Guru dibantu oleh teman sejawat sebagai observer. Pengamatan (observasi) dilaksanakan bersamaan dengan pelaksanaan belajar mengajar. Proses belajar mengajar mengacu pada rencana pembelajaran yang telah dipersiapkan.

Pada akhir proses belajar mengajar siswa diberi tes individu dengan tujuan untuk mengetahui tingkat keberhasilan siswa dalam proses belajar mengajar yang telah dilakukan. Tes yang diberikan berupa soal individu. Soal tes terdiri atas 10 soal obyektif berbentuk pilihan ganda. 
Tabel 1. Nilai Hasil Tes Siklus I Pertemuan I

\begin{tabular}{llcc}
\hline Nilai $(\mathrm{X})$ & Frekuensi (f) & $\mathrm{f} \%$ & \\
\hline$\geq 80$ & & 3 & 7,89 \\
$<80$ & & 35 & 92,19 \\
& $\sum \mathrm{f}=38$ & & 100 \\
\hline
\end{tabular}

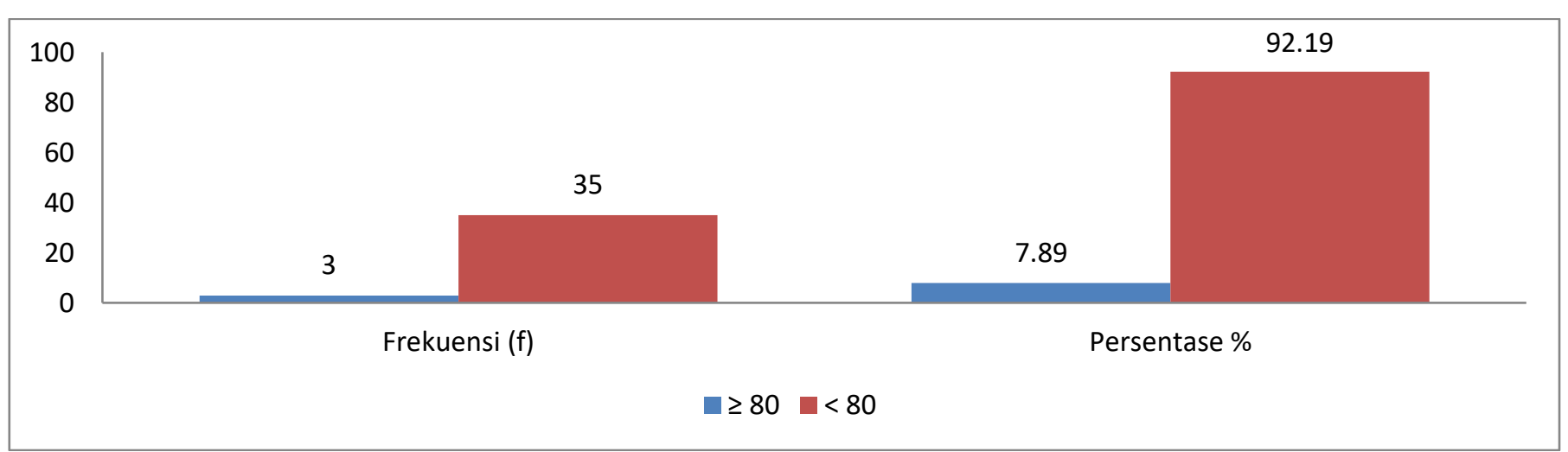

Grafik 1. Hasil Tes Siklus I Pertemuan I

Dari tabel dan grafik diatas dapat diketahui bahwa jumlah siswa yang memperoleh nilai 80 ke atas hanya berjumlah 3 siswa (7,89\%) dan yang memperoleh nilai di bawah 80 berjumlah 31 siswa $(92,19 \%)$.

Tabel 2. Nilai Hasil Tes evaluasi Siklus I Pertemuan II

\begin{tabular}{lccc}
\hline Nilai (X) & Frekuensi (f) & f\% \\
\hline$\geq 80$ & & 11 & 28,94 \\
$<80$ & 27 & 71,06 \\
& $\sum \mathrm{f}=38$ & 100 & \\
\hline
\end{tabular}

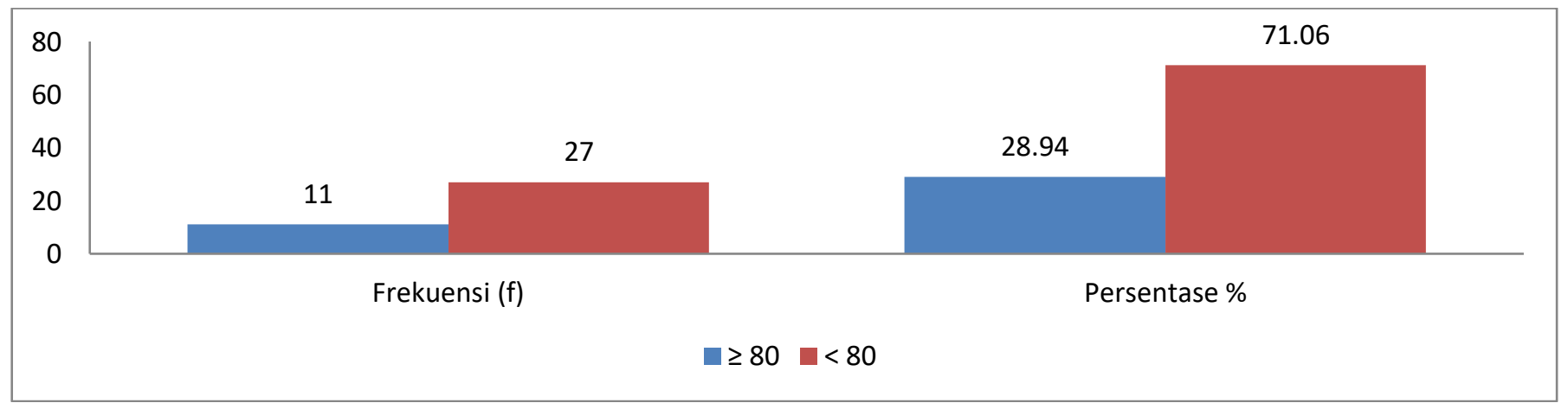

Grafik 2. Hasil Tes Siklus I Pertemuan 2

Dari tabel dan grafik diatas dapat diketahui bahwa jumlah siswa yang memperoleh nilai 80 ke atas hanya berjumlah 11 siswa $(28,94 \%)$ dan yang memperoleh nilai di bawah 80 berjumlah 27 siswa $(71,06 \%)$.

Nilai 80 adalah ketuntasan belajar, hasil tes evaluasi menunjukkan bahwa siswa yang dapat menguasai materi secara baik sehingga dapat mencapai ketuntasan belajar sebanyak 11 siswa $(28,94 \%)$ dan yang belum mencapai ketuntasan sebanyak 27 siswa $(71,06 \%)$. Hasil tes ini akan dijadikan dasar untuk melakukan perbaikan karena belum ada lebih dari $70 \%$ dari jumlah siswa yang mencapai ketuntasan belajar. Sehingga pada siklus selanjutnya penguasaan siswa terhadap materi selanjutnya dapat ditingkatkan.

Berdasarkan pengamatan terhadap keaktifan siswa pada siklus I, menunjukkan bahwa siswa telah berusaha untuk aktif dalam kegiatan pembelajaran. Berikut perolehan masing-masing aspek keaktifan siswa secara rinci, yaitu: 
Tabel 3. Pengamatan Keaktifan Siswa Siklus I

\begin{tabular}{|c|c|c|c|}
\hline No. & Indikator & $\begin{array}{l}\text { Jumlah } \\
\text { Siswa }\end{array}$ & $\begin{array}{c}\text { Persentase } \\
(\%)\end{array}$ \\
\hline 1. & Mencari dan memberikan informasi & 33 & 86,84 \\
\hline 2. & Bertanya pada guru atau siswa lain & 32 & 84,21 \\
\hline 3. & Mengajukan pendapat atau komentar kepada guru atau kepada siswa & 26 & 68,42 \\
\hline 4. & Diskusi atau memecahkan masalah & 21 & 55,26 \\
\hline 5. & Mengerjakan tugas yang diberikan oleh guru & 25 & 65,79 \\
\hline 6. & Memanfaatkan sumber belajar yang ada & 26 & 68,42 \\
\hline 7. & Menilai dan memperbaiki pekerjaannya & 30 & 78,95 \\
\hline 8. & Membuat simpulan sendiri tentang pembelajaran yang diterimanya & 26 & 68,42 \\
\hline 9. & Dapat menjawab pertanyaan guru dengan tepat saat pembelajaran & 25 & 65,79 \\
\hline 10. & Memberikan contoh dengan benar & 26 & 68,42 \\
\hline 11. & Dapat memecahkan masalah dengan tepat & 24 & 63,16 \\
\hline 12. & $\begin{array}{l}\text { Ada usaha dan motivasi untuk mempelajari bahan pelajaran dan stimulasi yang diberikan oleh } \\
\text { guru }\end{array}$ & 21 & 55,26 \\
\hline 13. & Dapat bekerja sama dan berhubungan dengan siswa lain & 28 & 73,68 \\
\hline 14. & Menyenangkan dalam pembelajaran & 28 & 73,68 \\
\hline 15. & Dapat menjawab pertanyaan yang diberikan oleh guru pada akhir pelajaran & 27 & 71,05 \\
\hline
\end{tabular}

Berdasakan persentase keaktifan siswa pada siklus I, yaitu sebagai berikut:

persentase keaktifan $=\frac{398}{570} \times 100 \%$

Jadi besarnya persentase keaktifan siswa siklus I adalah $69,82 \%$.

\section{Siklus 2}

Pembelajaran pada siklus II dilakukan selama 2 x 35 menit, dengan materi perubahan sosial budaya. Langkah - langkah pembelajaran sama dengan siklus I. Pada akhir proses belajar mengajar siswa diberi tes individu dengan tujuan untuk mengetahui tingkat keberhasilan siswa dalam proses belajar mengajar yang telah dilakukan. Tes yang diberikan berupa soal individu. Soal tes terdiri atas 10 soal obyektif berbentuk pilihan ganda.

Tabel 4 Nilai Hasil Tes Siklus 2 Pertemuan 1

\begin{tabular}{lccc}
\hline Nilai $(\mathrm{X})$ & Frekuensi (f) & & $\mathrm{f} \%$ \\
\hline$\geq 80$ & 24 & 63,15 \\
$<80$ & 14 & 36,85 & 100 \\
& $\sum \mathrm{f}=38$ & & 100 \\
\hline
\end{tabular}

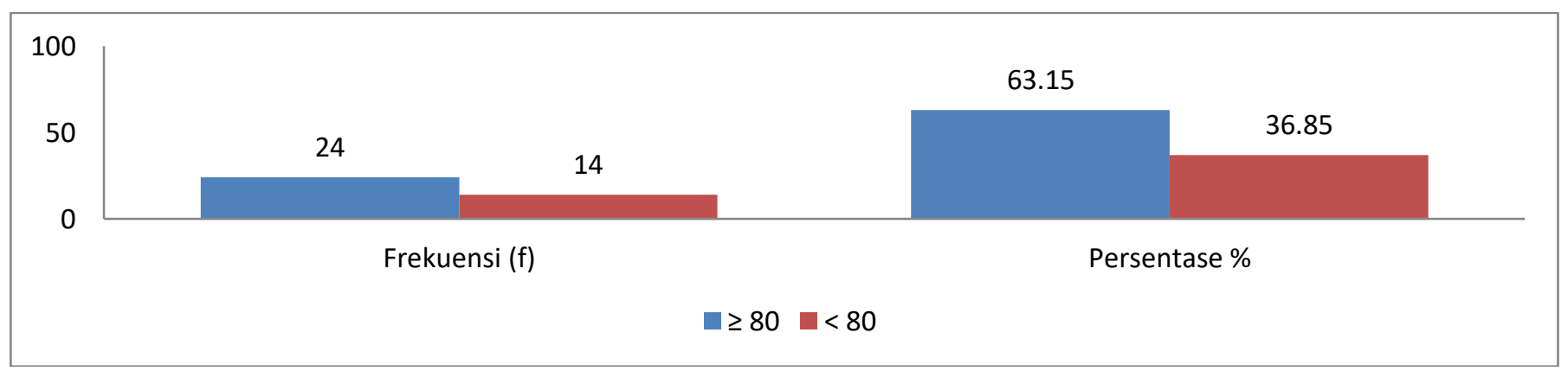

Grafik 3. Hasil Tes Siklus 2 Pertemuan 1

Dari tabel dan grafik diatas dapat diketahui bahwa jumlah siswa yang memperoleh nilai 80 ke atas hanya berjumlah 24 siswa $(63,15, \%)$ dan yang memperoleh nilai di bawah 80 berjumlah 14 siswa $(36,85,57 \%)$. 
Tabel 5. Nilai Hasil tes evaluasi Siklus II Pertemuan II

\begin{tabular}{|c|c|c|}
\hline Nilai (X) & Frekuensi (f) & $\mathrm{f} \%$ \\
\hline$\geq 80$ & 35 & 92,11 \\
\hline$<80$ & 3 & 7,89 \\
\hline & $\sum \mathrm{f}=38$ & 100 \\
\hline
\end{tabular}

\begin{tabular}{|l|r|rr|r|}
\hline 100 \\
50
\end{tabular}

\section{Grafik 4. Hasil Tes Siklus 2 Pertemuan 2}

Dari tabel dan grafik diatas dapat diketahui bahwa jumlah siswa yang memperoleh nilai 80 ke atas berjumlah 35 siswa $(92,11 \%)$ dan yang memperoleh nilai di bawah 80 berjumlah 3 siswa $(7,89 \%)$.

Nilai 80 adalah ketuntasan belajar, hasil tes evaluasi menunjukkan bahwa siswa yang dapat menguasai materi secara baik sehingga dapat mencapai ketuntasan belajar sebanyak 35 siswa (92.11\%) dan yang belum mencapai ketuntasan sejumlah 3 siswa (7,89\%). Jadi, sudah memenuhi setengah lebih jumlah siswa dalam kelas dan dapat dikatakan berhasil.

Berdasarkan pengamatan terhadap keaktifan siswa pada siklus II, menunjukkan bahwa siswa telah berusaha untuk aktif dalam kegiatan pembelajaran. Berikut perolehan masing-masing aspek keaktifan siswa secara rinci, yaitu:

Tabel 6. Pengamatan Keaktifan Siswa Siklus II

\begin{tabular}{|c|c|c|c|}
\hline No. & Indikator & $\begin{array}{l}\text { Jumlah } \\
\text { Siswa }\end{array}$ & $\begin{array}{l}\text { Persentase } \\
\quad(\%)\end{array}$ \\
\hline 1. & Mencari dan memberikan informasi & 35 & 100 \\
\hline 2. & Bertanya pada guru atau siswa lain & 36 & 77,78 \\
\hline 3. & Mengajukan pendapat atau komentar kepada guru atau kepada siswa & 33 & 63,89 \\
\hline 4. & Diskusi atau memecahkan masalah & 32 & 80,56 \\
\hline 5 . & Mengerjakan tugas yang diberikan oleh guru & 34 & 88,89 \\
\hline 6. & Memanfaatkan sumber belajar yang ada & 36 & 100 \\
\hline 7. & Menilai dan memperbaiki pekerjaannya & 33 & 80,56 \\
\hline 8. & Membuat simpulan sendiri tentang pembelajaran yang diterimanya & 35 & 55,56 \\
\hline 9. & Dapat menjawab pertanyaan guru dengan tepat saat pembelajaran & 34 & 55,56 \\
\hline 10. & Memberikan contoh dengan benar & 34 & 83,33 \\
\hline 11. & Dapat memecahkan masalah dengan tepat & 33 & 41,67 \\
\hline 12. & $\begin{array}{l}\text { Ada usaha dan motivasi untuk mempelajari bahan pelajaran atau stimulasi yang diberikan } \\
\text { oleh guru }\end{array}$ & 32 & 58,33 \\
\hline 13. & Dapat bekerja sama dan berhubungan dengan siswa lain & 32 & 63,89 \\
\hline 14. & Menyenangkan dalam pembelajaran & 33 & 83,33 \\
\hline 15. & Dapat menjawab pertanyaan yang diberikan oleh guru pada akhir pelajaran & 32 & 77,78 \\
\hline
\end{tabular}

Berdasakan persentase keaktifan siswa pada siklus II , yaitu sebagai berikut:

persentase keaktifan $=\frac{504}{540} \times 100 \%$

Jadi besarnya persentase keaktifan siswa siklus II adalah 88,427 \%. 


\section{Pembahasan}

Penelitian yang bertujuan untuk meningkatkan keaktifan dan hasil belajar IPS pada siswa Kelas VIII di SMP Negeri 24 Kota Jambi telah dilaksanakan dalam 2 siklus dan setiap siklus terdiri dari 2 kali pertemuan. Penelitian ini dilaksanakan pada bulan Oktober sampai November Tahun Ajaran 2018/2019.

Pada pembahasan dalam penelitian ini merupakan pembahasan yang mengarah pada hasil observasi selama penelitian. Penelitian tindakan kelas ini dilaksanakan untuk kemudian dilakukan refleksi pada tiaptiap siklusnya. Pelaksanaan pembelajaran dengan metode pembelajaran Time Token. Proses pembelajarannya meliputi (a) penyajian kelas yang berupa penyampaian informasi, (b) kegiatan belajar kelompok dengan metode Time Token, (c) pelaksanaan tes, dan (d) hasil tes yang berupa penghitungan skor kemajuan atau peningkatan. Pembahasan atas beberapa aktivitas yang dilakukan dengan metode pembelajaran Time Token pada mata pelajaran IPS adalah sebagai berikut:

\section{Penyajian Kelas (Penyampaian Informasi)}

Penyampaian informasi yang berupa materi pelajaran IPS dilakukan setelah tahap inti pelaksanaan pembelajaran diselesaikan. Penyampaian materi yang disajikan dikelas bertujuan agar siswa Kelas VIIID di SMP Negeri 24 Kota Jambi mempunyai gambaran yang jelas tentang materi yang akan dipelajari secara bersama-sama. Para siswa akan menyadari bahwa mereka harus benar-benar memperhatikan selama penyajian materi di kelas karena akan membantu mengerjakan tes.

\section{Kegiatan Belajar Kelompok dengan metode Time Token}

Agar dapat melaksanakan kegiatan belajar kelompok, guru membagi kelas menjadi beberapa kelompok dimana masing-masing kelompok terdiri dari 5-6 anggota yang terbagi secara heterogen. Siswa Kelas VIIID di SMP Negeri 24 Kota Jambi secara bersama-sama dengan anggota kelompoknya mengerjakan tugas yang telah diberikan.

Mereka saling berbagi dan menyimpulkan informasi serta saling membantu untuk mencapai tujuan bersama. Saat kegiatan belajar kelompok berlangsung, guru berkeliling mengawasi jalannya kegiatan belajar kelompok. Pembahasan hasil diskusi atau hasil kerja kelompok dengan metode Time Token, perwakilan dari tiap kelompok membacakan hasil dari kerja kelompok mereka dan kelompok lain mendengarkan, memberikan tanggapan maupun memberikan pertanyaan. Guru dan siswa mengakhiri diskusi dengan melakukan penarikan kesimpulan secara bersama-sama yang dilakukan dalam setiap siklus.

\section{Pelaksanaan Tes}

Setelah siswa bekerja dalam kelompok dengan metode Time Token dan pembahasan hasil kerja kelompok selesai, diadakan tes sebagai acuan untuk mengetahui skor kemajuan individu dan untuk mengetahui poin yang disumbangkan kepada kelompok agar memperoleh penghargaan kelompok. Hasil dari tes juga bertujuan untuk mengetahui kemampuan siswa setelah diberikan tindakan, sehingga dapat mengetahui peningkatan hasil belajar siswa. Saat mengerjakan tes diwajibkan untuk mengerjakan secara individu.

\section{Penghitungan Hasil Tes}

Skor kemajuan individu diperoleh dengan cara membandingkan skor tes terkini dengan skor awal. Siswa mengumpulkan poin secara individu berdasarkan tingkat di mana skor tes mereka meningkat atau menurun terhadap skor awal mereka. Penghitungan peningkatan skor individu ini dilakukan peneliti tanpa melibatkan siswa

Berdasarkan penjelasan diatas, maka dapat dilihat perbandingan hasil dari kinerja guru, aktivitas belajar, dan hasil belajar siswa menunjukkan adanya peningkatan sangat signifikan. Untuk itu dapat dilihat tabel berikut 
Tabel 7 Rekapitulasi Perbandingan Nilai Observasi Kinerja Guru, aktivitas siswa dan hasil belajar siswa siklus I, dan II

\begin{tabular}{|c|c|c|c|}
\hline No. & Hasil Penelitian & Siklus I & Siklus II \\
\hline 1. & Hasil belajar & 67,76 & 83,34 \\
\hline 2. & Aktivitas Siswa & 69,82 & 88,42 \\
\hline 3. & Aktivitas Guru & 70 & 90 \\
\hline
\end{tabular}

Berdasarkan tabel 7 menunjuk bahwa dari rekapitulasi perbandingan nilai obersevasi kinerja guru, aktivitas siswa dan hasil belajara mulai dari siklus I sampai dengan siklus II adanya peningkatan aktivitas dan hasil belajar siswa dalam menggunakan metode Time Token Kelas VIIID di SMP Negeri 24 Kota Jambi. Dengan demikian hasil perbandingan tersebut dapat dilihat pada grafik 4.5 di bawah ini.

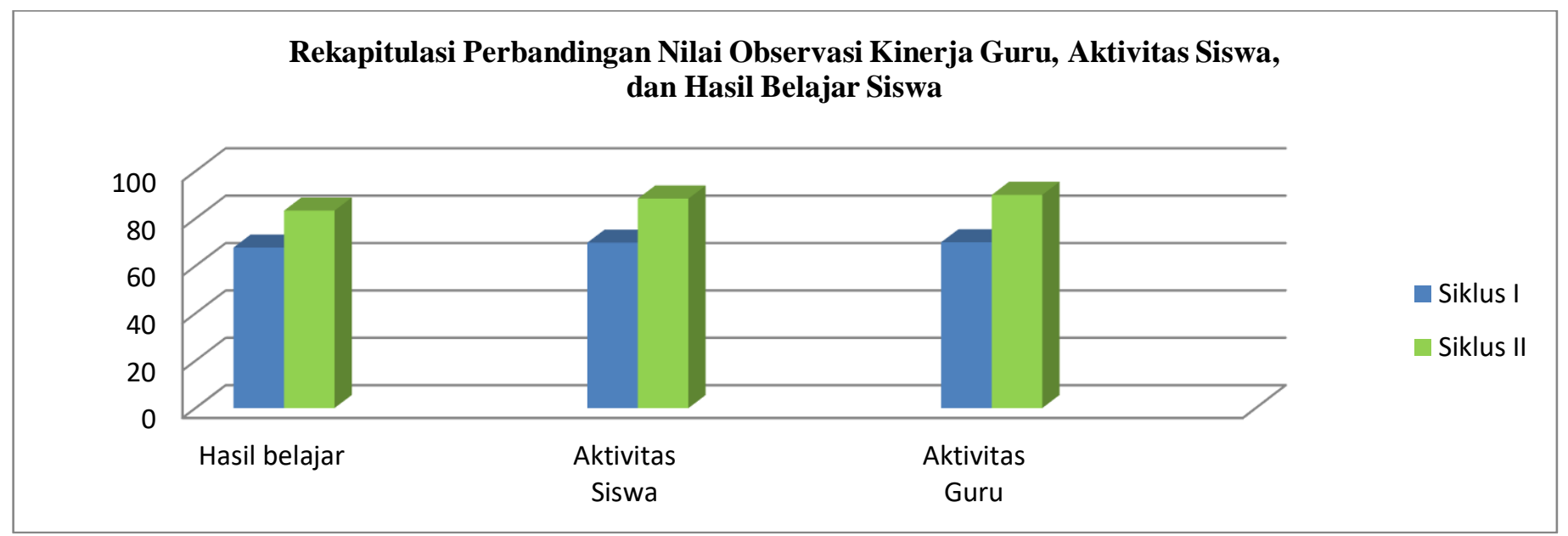

Grafik 5. Rekapitulasi Perbandingan Nilai Observasi Kinerja Guru, Aktivitas Siswa, dan Hasil Belajar Siswa Siklus I dan II

Data hasil observasi menunjukkan keaktifan siswa adalah sebagai berikut:

a. Mencari dan memberikan informasi pada siklus I sebesar $86,84 \%$ meningkat menjadi $92,11 \%$ pada siklus II. Saat siswa berdiskusi sudah mulai bisa mengungkapkan ide masing-masing siswa.

b. Bertanya pada guru atau siswa lain pada siklus I sebesar $84,21 \%$ tidak mengalami peningkatan menjadi 94,74\% pada siklus selanjutnya, siswa masih ada yang malu saat mau bertanya walaupun guru sudah mencoba memberi pengertian kepada siswa untuk bertanya dan tidak perlu malu pada siswa lain.

c. Mengajukan pendapat atau komentar kepada guru atau kepada siswa pada siklus I sebesar $68,42 \%$ dan meningkat menjadi $86,84 \%$ pada siklus II

d. Diskusi atau memecahkan masalah pada siklus I sebesar 55,262\% meningkat menjadi $84,21 \%$ pada siklus II .

e. Mengerjakan tugas yang diberikan oleh guru pada siklus I sebesar 65,79\% meningkat menjadi 89,47\% pada siklus II

f. Memanfaatkan sumber belajar yang ada pada siklus I sebesar $68,42 \%$ meningkat menjadi $86,84 \%$ pada siklus II. Siswa mulai memperhatikan dan mulai memahami arti pentingnya sumber belajar untuk berdiskusi.

g. Menilai dan memperbaiki pekerjaannya pada siklus I \% 78,95\%, siklus II menjadi $92,11 \%$.

h. Membuat simpulan sendiri tentang pembelajaran yang diterimanya pada siklus I $68,42 \%$ dan mengalami peningkatan menjadi $92,11 \%$ pada siklus 2 .

i. Dapat menjawab pertanyaan guru dengan tepat saat berlangsung KBM pada siklus I $65,79 \%$ dan tmengalami peningkatan pada siklus selanjutnya menjadi $89,41 \%$. Hanya siswa tertentu saja yang bisa menjawab pertanyaan guru dengan tepat.

j. Memberikan contoh dengan benar pada siklus I 68,42\% meningkat menjadi $89,47 \%$ pada siklus II

k. Dapat memecahkan masalah dengan tepat pada siklus I 63,16\% siklus II meningkat pada siklus II, yaitu sebesar $86,84 \%$.

1. Ada usaha dan motivasi untuk mempelajari bahan pelajaran atau stimulasi yang diberikan oleh guru pada siklus I sebesar 55,26\% dan mengalami peningkatan pada siklus berikutnya menjadi 84,21\%. 
m. Dapat bekerja sama dan berhubungan dengan siswa lain pada siklus I sebesar 73,68\% dan mengalami peningkatan pada siklus 2 menjadi $84,21 \%$.

n. Menyenangkan dalam KBM pada siklus I 73,68\% dan mengalami peningkatan menjadi $86,84 \%$ pada siklus II

o. Dapat menjawab pertanyaan yang diberikan oleh guru pada akhir pelajaran pada siklus I 71,05\% dan mengalami peningkatan menjadi $84,21 \%$ pada siklus II

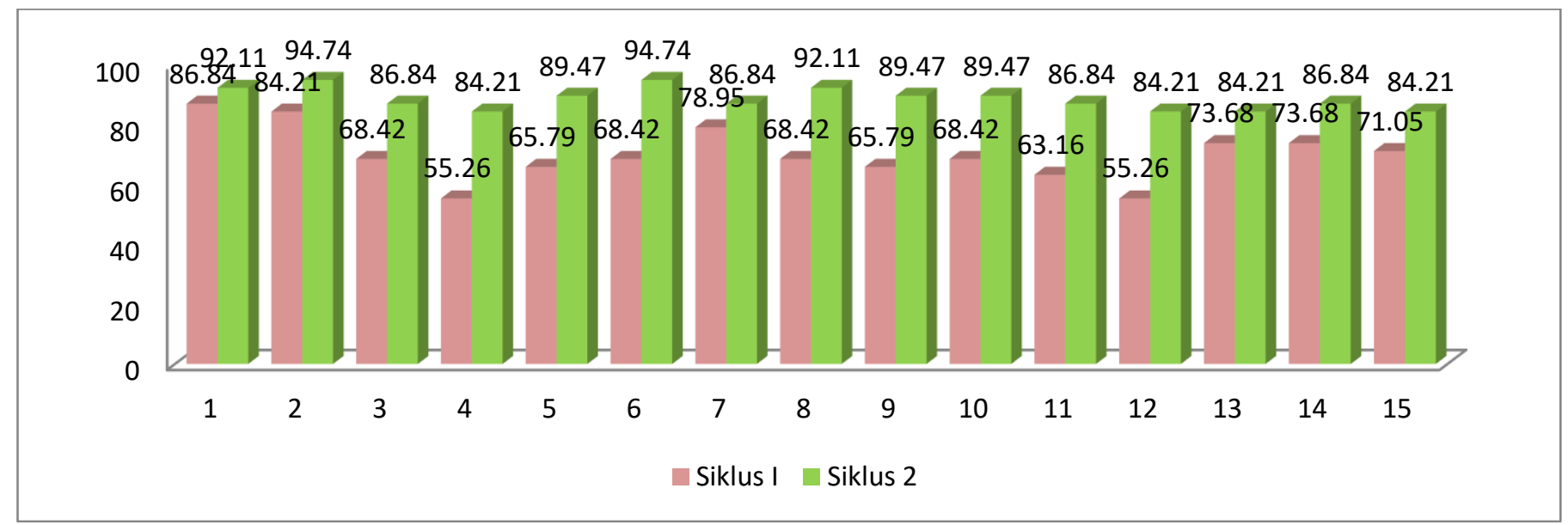

Grafik 6. Diagram Keaktifan Siswa siklus I dan Siklus II

Berdasarkan hasil tes terhadap hasil belajar siswa menunjukkan bahwa dari siklus I sampai siklus II mengalami peningkatan. Pada siklus I nilai siswa yang memenuhi nilai KKM, yaitu 80 adalah 11 siswa $(28,94 \%)$ dan pada siklus II mengalami peningkatan menjadi 35 siswa $(92,11 \%)$. Dapat dilihat pada diagram berikut.

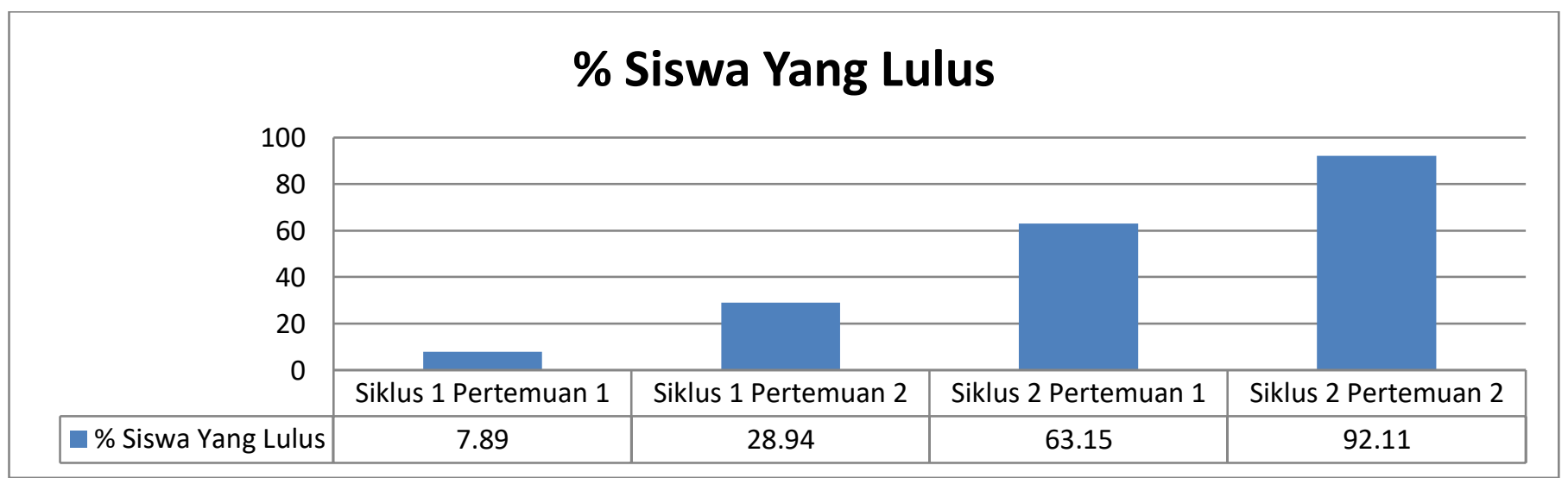

Grafik 7. Diagram Peningkatan \% Siswa Yang Lulus Pada Siklus I dan Siklus II

Aktivitas siswa dalam pembelajaran juga dipengaruhi oleh aktivitas guru dalam melaksanakan proses pembelajaran. Sehingga selain melakukan pengamatan terhadap siswa, peneliti juga melakukan pengamatan terhadap aktivitas guru di kelas. Guru telah berusaha menciptakan suasana pembelajaran yang kondusif. Hal ini dapat dilihat dari adnya peningkatan peran guru pada setiap pertemuan. Pada siklus I aktivitas guru ada yang tidak muncul, yaitu guru tidak memberikan motivasi pembelajaran yang menarik berkaitan dengan tujuan pembelajaran, tidak memberi pengalaman berbahasa kepada siswa, tidak memberikan tindak lanjut (perbaikan/pengayaan).

Hasil penelitian dan pembahasan di atas dapat disimpulkan bahwa metode pembelajaran Time Token untuk meningkatkan keaktifan dan hasil belajar IPS pada siswa Kelas VIIID di SMP Negeri 24 Kota Jambi telah berhasil. Hal ini dapat dibuktikan dengan meningkatnya keaktifan siswa dari siklus I sampai siklus II , yaitu dari 69,82 \% meningkat menjadi 88,42\% dan perolehan nilai tes yang sudah memenuhi KKM, yaitu 80 pada setiap siklus yang meningkat yaitu siklus I sebesar 7,89\%; dan siklus II sebesar 92,11\%. 
Penelitian ini berhenti pada siklus keduaa karena pada siklus II semua indikator keberhasilan sudah terpenuhi, yaitu sudah mencapai $70 \%$ dari jumlah siswa baik keaktifan maupun hasil belajarnya.

\section{SIMPULAN}

Berdasarkan hasil penelitian dan pembahasan, dapat diambil kesimpulan bahwa:

1. Upaya meningkatkan keaktifan dan hasil belajar IPS melalui metode pembelajaran Time Token pada siswa Kelas VIIID di SMP Negeri 24 Kota Jambi dapat dilaksanakan dengan cara melalui semua komponen atau karakteristik Time Token yang terangkum dalan 15 indikator selama pembelajaran meliputi: penyampaian informasi (penyajian kelas), kegiatan belajar kelompok dengan metode Time Token, pelaksanaan tes, dan skor peningkatan individu. Aktivitas siswa dan guru semakin meningkat dari siklus I sampai dengan siklus II.

2. Bukti peningkatan keaktifan dan hasil belajar pada mata pelajaran IPS setelah menggunakan metode pembelajaran Time Token selama pelaksanaan tindakan mengalami peningkatan, yaitu:

a. Peningkatan keaktifan, rata-rata keaktifan siklus I sebesar 69,82 \%. Pada siklus II mengalami peningkatan menjadi $88,42 \%$.

b. Peningkatan hasil belajar siswa yang sudah memnenuhi nilai ketuntasan, yaitu pada siklus I sebesar 7,89\%. Pada siklus II mengalami peningkatan, yaitu menjadi menjadi sebesar 92,11.

\section{DAFTAR PUSTAKA}

Agus Suprijono. (2011). Cooperative Learning Teori \& Aplikasi PAIKEM. Yogyakarta: Pustaka Pelajar.

Miles, Matthew B. and Huberman, A. Michael. (1992). Analisis Data Kualitatif. Jakarta: UI Press.

Peraturan Menteri Pendidikan Nasional No. 22 Tahun 2006 tentang Standar Isi untuk Satuan Pendidikan Dasar dan Menengah. Jakarta: CV Eka Jaya.

Peraturan Perundang-undangan Republik Indonesia No. 19 Tahun 2005 tentang Standar Nasional Pendidikan. Jakarta: Sinar Grafika.

Ratna Wilis Dahar. (1988). Teori- teori Belajar. Jakarta: P2LPTK.

Sapriya. (2011). Pendidikan IPS: Konsep dan Pembelajaran. Bandung: PT Remaja Rosdakarya.

Sardiman A. M. (2003). Interaksi dan Motivasi Belajar Mengajar. Jakarta: Rajawali Press.

Silberman, Melvin L. (2009). Active Learning: 101 Cara Belajar Siswa Aktif(Alih bahasa: Raisul Muttaqien). rev.ed. Bandung: Nusamedia.

Slavin, Robert E. (2010). Cooperative Learning Teori, Riset, dan Praktik (Alih bahasa: Narulita Yusron). Bandung: Nusa Media.

Suwarsih Madya. (2007). Teori dan Praktik Penelitian Tindakan. Bandung: Alfabeta.

Undang-undang Republik Indonesia No. 20 Tahun 2003 tentang Sistem Pendidikan Nasional. Jakarta: Depdiknas. 